\title{
Practitioner Inquiry with Early Program Teacher Candidates
}

\author{
Michele Hollingsworth Koomen \\ Correspondence: Michele Hollingsworth Koomen, USA. \\ Received: September 5, 2016 \\ doi:10.11114/jets.v4i11.1915 \\ Accepted: September 22, 2016 \\ Online Published: October 8, 2016 \\ URL: http://dx.doi.org/10.11114/jets.v4i11.1915
}

\begin{abstract}
This meta-analysis reports on the use of practitioner inquiry (PI) with early program teacher candidates in conjunction with elementary science and math methods courses using cognitive load theory as a theoretical framework. The findings suggest that the teacher candidates enhanced their knowledge of practice within practice across 5 dimensions of practice: inclusion, classroom discussion, classroom engagement, understanding student learning and grouping. The sixth outcome provides evidence of the ways that the practitioner inquiry fostered learning about how to learn from practice. Cognitive load theory can be used to explain the difficulty of assimilating theory into practice for emerging teacher candidates. Implications for teacher education are included.
\end{abstract}

Keywords: cognitive load theory, elementary teacher education, practitioner research, teacher candidates

\section{Introduction}

Darling-Hammond asserts that over the past two-decades considerable progress has been made in teacher education as a result of research and policy initiatives (2010). Teacher education has tapped the "wisdom of practice" with direct involvement of strong practitioners and is better at connecting theory to practice with clinical experiences, often using professional development schools, action research, case students and performance assessments (p. 36). However, one of the central challenges of teacher education argues Darling-Hammond is "how to foster learning about and from practice in practice" (p. 42). Ball and Forzani (2009) contend that teacher education is often "centered not on the tasks and activities of teaching but on beliefs and knowledge, on orientations and commitments, and a policy environment preoccupied with recruitment and retention" (p. 498). In addition, Hiebert and Morris (2012) call for significant research efforts that turn the focus from teachers to an emphasis on teaching because working directly on improving teaching is one of the most productive methods to impact classroom instruction. The intent of the current study is to engage early program teacher candidates in practitioner inquiry of their own teaching to provide them with more explicit opportunities to focus on the tasks and activities of teaching, thus this work addresses the call to teacher education to foster learning from practice in practice with an emphasis on teaching.

Cochran-Smith, Barnatt, Friedman and Pine describe practitioner inquiry as a variety of "research modes, forms, genres and purposes" (2009) that encompass action research, teacher research, self-study, the scholarship of teaching and learning and the use of teaching as a context for research. Each of the preceding genres originates in different historical and epistemological traditions, but they share one important commonality: the practitioner (the teacher) takes on the role simultaneously as a researcher. As a result, the boundaries between the teacher and the researcher are blurred. Practitioner inquiry is defined by Richardson (1994) as research that is conducted by teachers to help them "understand their contexts, practice, and their students" all with an expected outcome of enhancing practice. Practitioner inquiry and research reflect the day-to-day work of a teacher and result in improvement to practice.

Practitioner inquiry has produced a rich body of research in teacher education programs in the United States and across the world including, the Netherlands, the United Kingdom, Canada, Australia and New Zealand where educators are encouraged to engage in "critical reflection, develop a questioning stance, understand school culture, construct new curriculum and pedagogy, and modify instruction to meet students' needs" (Cochran-Smith, et 1., 2009). With its focus on teaching, practitioner inquiry has been key to innovations in teaching diverse subject areas such as mathematics, science, writing, language arts and social studies (Cochran-Smith \& Lytle, 2009; Daiker \& Morenburg, 1990; Edelsky, 1991; Lampert, 1990) and complex teaching challenges such as teaching for social justice (Cochran-Smith and Lytle, 2004). 
Despite numerous publications on practitioner inquiry, the literature in the area of pre-service practitioner inquiry is sparse. Cochran-Smith authored a number of articles documenting her efforts to enhance student teachers' understanding and address issues of social justice and diversity (1991, 1995 and 1999). Levin and Rock (2003) and Rock and Levin (2002) published twice regarding the development of teacher candidates' ideas and beliefs about teaching, learning and diversity as a result of practitioner inquiry. Price (2001) and Price and Valli (2005) studied both the positive and unintended outcomes of encouraging teacher candidates to engage in practitioner research. The teacher candidates involved in the above studies were all student teachers in their last year of their teacher education programs, whereas this study focused on teacher candidates in a short (3-4 week) field experience coupled with elementary science and mathematics methods courses where the majority of the teacher candidates were completing their third year in a four-year program. Additionally, findings from an application of practitioner inquiry with short field experiences might provide more flexible implications for teacher education programs. This paper takes up the call to teacher education for research in learning from practice in practice with a focus on teaching rather than teachers in a process that fosters continuous improvement and a generous regard for the field of practice, all with early program undergraduate teacher candidates with an eye for producing "well-started novices" (Sykes, Bird \& Kennedy, 2010).

\section{Theoretical Framework}

This study used cognitive load theory (CLT) from the cognition and learning research as the theoretical framework. Cognitive load is simply described as the amount of mental effort that a learner expends completing a task (Kirschner, Ayres, \& Chandler, 2011) and "is concerned with the manner in which cognitive resources are focused and used during learning and problem solving" (Chandler \& Sweller, 1991). It is an index of the "number of non-automatic elaborations [in working memory] necessary to solve a problem" (Salomon, 1984). CLT focuses on the relationship between long and short-term memory (Moos \& Pitton, 2014) originating in human cognitive architecture consisting of limited working, short-term or conscious memory, which interacts with a comparatively unlimited long-term memory (Kirschner, et al.). In 1956 Miller established that working memory was limited and could hold only 7 elements or bits of information at a time. Because working memory is most often used to process information in the sense of "organizing, contrasting, comparing, or working on that information in some manner, humans are probably only able to deal with two or three items of information simultaneously when required to process rather than merely hold information" (Sweller, van Merrienboer \& Paas, 1998).

Long-term memory is the lasting storage of information into structures called schemas. A schema categorizes information in the manner in which it will be used (Chi, Glaser, \& Rees, 1982). Schema has two functions: the storage and organization of information in long-term memory and a reduction of working memory load (Sweller et al., 1998). Learning that has occurred over a long period of time will result in schema that have a huge store of information.

Sweller (1999) outlined three different categories of cognitive load based on the properties of the tasks performed: intrinsic load, extraneous load, and germane load. Intrinsic cognitive load occurs when the learner engages in cognitive processes that are essential for comprehending the material and is a function of the inherent difficulty and complexity of the task itself. In the context of teaching, this would include both the content and the pedagogy of a lesson (Feldon, 2007). Extraneous cognitive load represents unnecessary structural or semantic content that is not relevant to the task at hand yet occupies working memory. Extraneous cognitive load results when the learner engages in cognitive processing that does not contribute to the successful completion of the learning task, which can be a result from poor layout, instruction, etc. (Moos \& Pitton, 2014). For example, in teaching extraneous load might be distractions such as a visitor to the classroom, voices heard from the hallways outside of the classroom or the presence of an observing supervisor from the university-based teacher education program (Moos \& Pitton). Germane cognitive load occurs when the learner engages in deep cognitive processes such as relating it to prior knowledge (which reflects the learner's level of prior domain knowledge in addition to well-designed instruction such as effective scaffolding, prompts, etc.) (Moos \& Pitton). It develops in the presence of information or elements of a task that allow a task to be completed (Moos \& Pitton) and thus build schematic structures (Sweller et al., 1998). Germane load is that load that is dedicated to the construction, processing and automation of schemas. For example, in addition to both the content of the lesson and the pedagogy (intrinsic cognitive load), teachers have to pay attention to the prior knowledge of the students, be aware of verbal and nonverbal cues from students, and monitor student attention and engagement in the lesson, all of which impact germane cognitive load and the ability to create permanent schema (Moos \& Pitton; Sweller et al., 1998). The three different categories of cognitive load are also additive in nature (van Merriënboer \& Sweller, 2005). Theoretically, cognitive overload occurs when the total processing demands of external stimuli and internal cognitions exceed the capacity of working memory (Sweller, 1988). Thus, levels of cognitive load impact learning and performance (e.g. Sweller, 1988; Sweller, van Merrienboer \& Paas, 1998).

The sheer amount of both sensory and semantic information available to a teacher in a classroom setting is phenomenal. It should come as no surprise that novice teacher candidates report feeling overwhelmed (e.g. Feiman-Nemser, S., 2001; 
Kagan \& Tippins, 1992). Experienced teachers have created extensive knowledge bases of both content and pedagogy and are able to differentiate between relevant and irrelevant (extraneous cognitive load) cues in a classroom (Allen \& Casbergue, 1997; Kagan \& Tippins, 1992). Thus, expert teachers allocate far greater attention to matters that relate to germane cognitive load in their teaching and thus continue to build their cognitive schemas (Berliner, 1986; Sternberg \& Horvath, 1995; Sweller et al., 1998). In addition, prior knowledge ensures that the limited space of working memory is used more efficiently (Gobet \& Simon, 1998; Masunaga \& Horn, 2000). Experienced and expert teachers have reached a level of automaticity for interpreting, evaluation and responding to classroom events requiring little cognitive load (Blessing \& Anderson, 1996).

This study, with a focus on early program novices, builds on recent research in CLT with preservice teachers (Moos \& Pitton). As noted earlier, practitioner inquiry with teacher candidates is not well documented in the literature with an absence, too, of the use of cognitive load theory as a theoretical framework. The author hypothesized that cognitive load theory might explain the learning about practice from practice that was uncovered by the teacher candidates through their use of practitioner inquiry. This research was guided by the following research questions:

1). In what ways does a study of teaching enhance learning from practice in practice?

2). To what extent is the enhanced knowledge of practice explained by cognitive load theory?

\section{Research Methods}

\subsection{Context of the Study}

This study is situated in two separate but integrated elementary science and mathematics methods courses for elementary education majors at an undergraduate, residential liberal arts college in the Upper-Midwest of the U.S. Students enrolled in the two courses are generally third year students in a four year program of teacher education concurrently enrolled in teaching methods courses in language arts, mathematics, reading, science and social studies, a kindergarten curriculum and methods course and an interdisciplinary course. The methods courses meet for the first half of the sixteen-week semester in two-hour blocks twice per week. About week nine, the candidates begin a full day, every day, 3-4 week practicum placement co-teaching in pairs or trios in local schools. The practicum experience concludes at week thirteen and students return to campus for the final weeks of the semester.

The context for the study originates in a capstone project of the science and mathematics methods courses called a Study of Teaching (SOT). While in practica, teacher candidates videotape their teaching (5 lessons). After watching their teaching episodes and taking copious notes, teacher candidates identify a practice, phenomenon or dynamic for deeper study. Promising studies assert that the use of video technology is helpful in promoting pre-service teachers' analysis of their own teaching (Calandra, Gurvitch, \& Lund, 2008). Videotape allows teachers an opportunity to see beyond the demands of the immediate classroom instructional needs (Sherin, 2000). The use of video paves the way for an "analytic mind set," and promotes a different kind of knowledge beyond the conundrum of "what to do next?," and offers an opportunity to interpret and reflect on classroom practice" (Sherin 2004).

Next the teacher candidates conduct a modified research literature review to understand the phenomenon within the context of published research. The goal of this research review is not to be inclusive of all the prominent research of the phenomenon, but to broaden their knowledge of what is currently known. The final step is a written paper where the teacher candidates synthesize their research outcomes within the context of the research literature and identify the implications of their new knowledge about their practice for student teaching and beyond. The completed research projects are presented to the whole class in a symposium on the last day of class.

\subsection{Participants}

Forty-two student pairs and twelve trios completed the SOT. Table 1 includes the names (pseudonyms), grade levels, enrolled semester, focus topic of study, research question and data collections methods for each pair or trio. 
Table 1. Names, grade level, enrolled semester and summary of practitioner research

\begin{tabular}{|c|c|c|c|c|}
\hline Names & Grade level & Semester & $\begin{array}{l}\text { Focus of study and research } \\
\text { question }\end{array}$ & Data collection \\
\hline Laurie/Justine & 4 & Fall 2014 & $\begin{array}{l}\text { Inclusion: What strategies can we } \\
\text { implement in our future } \\
\text { classrooms that will help us reach } \\
\text { the needs of our LD and ELL } \\
\text { students? }\end{array}$ & $\begin{array}{l}\text { Anecdotal notes, video-taped } \\
\text { analysis, interviews of cooperating } \\
\text { teacher special education teacher, } \\
\text { and three students }\end{array}$ \\
\hline Roberta/Piper & 5 & Spring 2009 & $\begin{array}{l}\text { Inclusion: How can we provide } \\
\text { students of "average" ability with } \\
\text { the attention and accommodations } \\
\text { they need without neglecting the } \\
\text { below average and above average } \\
\text { students? }\end{array}$ & $\begin{array}{l}\text { Anecdotal notes, video-taped } \\
\text { analysis, interviews of three } \\
\text { classroom teachers }\end{array}$ \\
\hline Kara/Aubrey/Helen & 5 & Fall 2012 & $\begin{array}{l}\text { Inclusion \& student learning: In } \\
\text { what ways do we include middle } \\
\text { achieving students in our } \\
\text { classroom? }\end{array}$ & $\begin{array}{l}\text { Anecdotal notes, video-taped } \\
\text { analysis, interviews of all } 6 \text { of } \\
\text { invisible middle students }\end{array}$ \\
\hline Audrey/Trevor & 5 & Fall 2009 & $\begin{array}{l}\text { Inclusion: In what ways was } \\
\text { gender inequity a part of our } \\
\text { classroom teaching and learning? }\end{array}$ & $\begin{array}{l}\text { Anecdotal notes, video-taped } \\
\text { analysis, interviews of all } 2 \\
\text { in-service teachers }\end{array}$ \\
\hline Emma/Carol/Ellen & 4 & Spring 2014 & $\begin{array}{l}\text { Classroom engagement: How do } \\
\text { the strategies of wait time affect } \\
\text { the occurrence of student } \\
\text { response? }\end{array}$ & $\begin{array}{l}\text { Anecdotal notes, video-taped } \\
\text { analysis, interviews of four } \\
\text { students, cooperating teacher and } \\
\text { elementary principal }\end{array}$ \\
\hline Beatrice/Hanna & 1 & Spring 2015 & $\begin{array}{l}\text { Classroom engagement: Where do } \\
\text { we see students who are engaged } \\
\text { and unengaged in our lessons? }\end{array}$ & $\begin{array}{l}\text { Anecdotal notes, video-taped } \\
\text { analysis, interviews of two } \\
\text { in-service teachers }\end{array}$ \\
\hline Angelique and Janel & $\begin{array}{l}\text { Multi-age } \\
1 / 2\end{array}$ & Fall 2009 & $\begin{array}{l}\text { Classroom engagement: What are } \\
\text { effective methods/strategies of } \\
\text { getting and keeping students' } \\
\text { attention during a lesson? }\end{array}$ & $\begin{array}{l}\text { Anecdotal notes after teaching, } \\
\text { video-taped analysis, observational } \\
\text { notes of videos, interviews of three } \\
\text { in-service teachers including } \\
\text { cooperating teacher }\end{array}$ \\
\hline Kayla/Reese & 5 & Spring 2015 & $\begin{array}{l}\text { Classroom engagement: What } \\
\text { strategies did preservice teachers } \\
\text { use to regain the attention of the } \\
\text { students when they were off task? }\end{array}$ & $\begin{array}{l}\text { Anecdotal notes, video-taped } \\
\text { analysis, interviews of two } \\
\text { in-service teachers }\end{array}$ \\
\hline Padao/Heidi & 2 & Spring 2015 & $\begin{array}{l}\text { Student learning: In what ways did } \\
\text { we understand our students } \\
\text { learning? }\end{array}$ & $\begin{array}{l}\text { Anecdotal notes, video-taped } \\
\text { analysis, interviews of two } \\
\text { education professors, and review of } \\
\text { student work samples }\end{array}$ \\
\hline Monisha/Holly & 1 & Fall 2010 & $\begin{array}{l}\text { Student learning: In what ways } \\
\text { can formative assessment best } \\
\text { implemented in the classroom be } \\
\text { beneficial to the learning process? }\end{array}$ & $\begin{array}{l}\text { Anecdotal notes, video-taped } \\
\text { analysis, interviews of two } \\
\text { in-service teachers, and review of } \\
\text { student work samples }\end{array}$ \\
\hline Alissa/Eleanor & $\begin{array}{l}\text { Multi-age: } \\
1-3\end{array}$ & Spring 2009 & $\begin{array}{l}\text { Grouping: How do our students reac } \\
\text { both behaviorally and academically } \\
\text { to the following grouping scenario: } \\
\text { during math and science lessons } \\
\text { individual, partner, small group, anc } \\
\text { large group? }\end{array}$ & $\begin{array}{l}\text { Anecdotal notes, video-taped } \\
\text { analysis, interviews of two } \\
\text { in-service teachers }\end{array}$ \\
\hline Mohammed/Jennifer & 6 & Spring 2014 & $\begin{array}{l}\text { Grouping: Does ability groupin } \\
\text { impact who we call on in clas: } \\
\text { discussions? }\end{array}$ & $\begin{array}{l}\text { Anecdotal notes, video-taped } \\
\text { analysis, interviews of two } \\
\text { in-service teachers and four students }\end{array}$ \\
\hline
\end{tabular}

\subsection{Data Collection}

Data collection and analysis drew from the multi-tiered model of Lesh and Kelly (2000). In the current study, Tier 1 refers to the teacher candidates and their practitioner inquiry while Tier 2 refers to the teacher educator and author who concentrated on the emerging knowledge of practice of the teacher candidates. A basic assumption of multi-tiered teaching research is that in spite of the differences between the levels (teacher candidates and teacher educator/researcher), they are all engaged in making sense of the experiences. The teacher candidates act as investigators as well as participants and the researcher acts as teacher as well as investigator. Tier 1 was data collected by the teacher candidates with Tier 2 data collected by the teacher educator and author. Table 2 lists the data collection points and the analysis for both teacher candidates and the teacher educator. 
Table 2. Data points and analysis for teacher candidates and teacher educator

\begin{tabular}{llll}
\hline Teacher Candidates & Analysis & Teacher Educator & Analysis \\
\hline $\begin{array}{l}\text { Video-tapes of science and } \\
\text { mathematics lessons }\end{array}$ & QDA & $\begin{array}{l}\text { Study of Teaching written papers and } \\
\text { presentations, } \\
\text { Observational notes from presentations }\end{array}$ & $\begin{array}{l}\text { Grounded } \\
\text { theory \& CLT } \\
\text { Grounded } \\
\text { theory \& CLT }\end{array}$ \\
$\begin{array}{lll}\text { Gideo-taped analysis records/notes } & \text { QDA } & \text { Anecdotal notes during and after class } \\
\text { theory \& CLT }\end{array}$ \\
$\begin{array}{l}\text { Student work samples } \\
\begin{array}{l}\text { Anecdotal notes after real-time } \\
\text { teaching }\end{array}\end{array}$ & QDA & $\begin{array}{l}\text { Written and oral reflections from the } \\
\text { teacher candidates }\end{array}$ & $\begin{array}{l}\text { Grounded } \\
\text { theory \& CLT } \\
\text { Grounded } \\
\text { theory \& CLT }\end{array}$ \\
\hline
\end{tabular}

Tier 1: Teacher candidates. Teacher candidate data collection points (Table 2) included: video-tapes of their science and mathematics lessons, video-taped analysis records/notes, semi-structured interviews of in-service classroom teachers, including for many their cooperating teachers, students in their classrooms or education professors, review of student work samples and review of their own anecdotal notes after real-time teaching.

Tier 2: Teacher educator. Data collection by the teacher educator (Table 2) included the Study of Teaching written papers and presentations, observational notes from the presentations, anecdotal notes during and after class where mentoring and guidance of the SOT process was the primary topic, written reflections from the teacher candidates at the end of the methods semester (after practicum), and semi-structured interviews of seven randomly selected teacher candidates after completion of the full teacher education program, including student teaching.

\section{Analysis}

Like the data collection efforts, the analysis was also multitiered.

\subsection{Tier 1: Teacher Candidates}

After initial review of the teaching videos and selection of a practice for study, the teacher candidates began an analysis of their teaching episodes. Teacher candidates used a semi-structured question format (transcribed verbatim) in conducting their interviews, starting with a set of questions and following up as needed with additional probing questions (Rubin \& Rubin, 2004). The students analyzed the sum of their data using qualitative data analysis (QDA) following Seidel's model (1998) of noticing, collecting and thinking of interesting "things" that is rigorous, yet, simple. The iterative and recursive nature of this process is due to the repetitious cycle that characterizes QDA. The process of QDA is overviewed within the days leading up to the practica experience. Once practica was complete, mentored conversations of the author with the teacher candidates allowed the three categories of the Seidel model to be situated within the candidates' data. Additionally, and for some groups, the quantitative data was analyzed using SPSS (Chi-squared, $t$-test or an ANOVA), by the author.

\subsection{Tier 2: Teacher Educator}

Grounded theory (Strauss \& Corbin, 1990) was the analytical tool used by the author in the meta-analysis (Tier 2). The analysis began with a close reading of the text, line by line. Like QDA, the grounded theory framework begins with a coding process. The initial phase of coding is called open coding and is concerned with identifying, naming, categorizing and describing phenomena found in the text. In the opening coding step, single word or short phrases were used by the author as codes for text such as: challenges, marginalized students, planning, grouping, grade levels, aha, student participation, uneven teacher interactions with students, frustrations, working memory, missed opportunities, and on and off task behaviors. These initial codes were hand written in the left margins of the text of the data. Axial coding, the process of finding relationships between categories and subcategories, is the next step in grounded theory analysis. The aim of the axial coding process is to discover how categories relate to subcategories in terms of their properties, dimensions and incidents (Strauss and Corbin, 1998) with the data put "back together in new ways by making connections between a category and a subcategory" (Strauss \& Corbin, p. 97). In this step, the author sorted open coding text excerpts into axial codes that categorized and grouped the codes by their properties, dimensions or incidents. For example, the open codes of marginalized students and uneven teacher interactions were placed together in an axial code labeled aspects of exclusion with working memory, ahas and missed opportunities as the category placed in the axial code of possible elements of CLT (extraneous, intrinsic, germane and overload). The final step in grounded theory analysis is to build the "story" through identification of selective codes that connect the axial codes together in an integrative process of "systematically relating it to other categories, validating these relationships by searching through confirming and disconfirming examples and filling in categories that needed further refinement and development" (Strauss \& Corbin). In this step, other axial codes such as gender bias, invisible students and aspects of 
exclusion built a story for dimensions of practice: inclusion, one of the first selective codes. Likewise, the axial code of possible elements of CLT was refined to reflect evidence for CLT. In addition, the sum of the data was reviewed specifically for examples of knowledge of practice that would disconfirm the tentative findings.

\section{Results}

This study sought to understand the enhancement of learning about practice from within through the use of practitioner inquiry with emerging teacher candidates using cognitive load theory as a theoretical and analytical framework. The results presented here represent the author's (Tier 2) analysis of the teacher candidates' projects, reflections by the teacher candidates (after practicum completed), semi-structured interviews, and anecdotal notes (Table 2). The findings of this study focus on the learning from practice within practice of the top five dimensions of practice identified by almost $85 \%$ of the teacher candidates as a result of the analysis (Tier 2) by the author: inclusion, classroom discussion, classroom engagement, understanding student learning and grouping. Twelve randomly selected teacher candidate studies representing the five top teaching dimensions provide the evidence of learning from practice within practice. The sixth outcome provides evidence of the ways that the practitioner inquiry fostered learning about how to learn from practice. Together these six dimensions of learning about practice from practice answer the first research question. For readability, each identified dimension of practice is a synthesis first of the outcomes of the representative 12 studies drawn from the meta-analysis of data collection efforts (Table 2), including text excepts or findings that illustrate elements and evidence of cognitive load theory [noted in brackets]. In this study the data was analyzed after the moments of teaching, thus the evidence for CLT is retrospective as well.

\subsection{Inclusion}

Fourteen student pairs/trios focused on aspects of inclusion including, supporting multi-lingual, special education and the invisible "middle" or average students and unintentional gender bias. Laurie and Justine ( $4^{\text {th }}$ grade placement) found as they reviewed their videos that students who were either multi-lingual or identified with an exceptionality (learning disability) looked "lost." Their attention seemed to wander to other students or objects within the classroom when they were teaching. An aspect of their practice that they were not cognizant of during the actual teaching [cognitive overload]. Their videos also revealed that more often than not those students would look at their neighbor's paper to understand what they were expected to do.

When watching our videos, we noticed that our non-English speaking and students identified with a learning disability seemed to be off task and not focused on the assignment at hand. While we were giving directions for the lessons, these students were looking around and not focused on the front of the classroom. (SOT manuscript)

Upon examination of relevant research literature, they realized that the inattention was probably an inaccurate way to describe the students' behavior. The students were likely engaged in using contextual and visual cues (anchor charts, for example) to comprehend the content of the lesson (Koomen, 2016; Quinn, Lee, \& Valdés, 2012; Stockall and Gartin, 2002). The use of the practitioner inquiry cast the teacher candidates as deliberate intellectuals who theorized practice as part of practice (Cochran-Smith \& Lytle, 2009). This stance provided them agency as thoughtful creators of their own knowledge of practice within relevant theory.

For two groups, watching their videotapes and reviewing their anecdotal notes revealed a specific group of students that they ignored: the average, invisible or middle student. Roberta and Piper sought to understand the number of times they called on or interacted with students from three teacher select student groups (gifted, average and high needs) in their $5^{\text {th }}$ grade classroom. During independent work time they found that that they interacted more frequently with the high needs students compared to the gifted and average, a result that was significant $\left(X^{2}=28.00, d f=2, p<0.0001\right)$.

After reviewing the videotapes of us teaching five lessons, two math and three science, we discovered that we devote a significant amount of time to the lower ability and the higher ability students in our attempts to equalize instruction. In doing this, we realized that we have unintentionally passed over the "average" students in our classroom [cognitive overload]. Our desire to help the lower students understand and to challenge the higher students left out a significant number of students who were caught in the middle (SOT manuscript).

During question and answer periods the number of times both Roberta and Piper called on students from the three teacher-selected groups was also significant $\left(X^{2}=8.83, d f=2, p<0.0121\right)$, with more students identified as gifted being called on rather than the other two groups. They noted that in classroom questioning they tended to call on the first hand that went up after they asked a question [cognitive overload]. That first hand was most often a student identified as gifted, rather than average or high needs students.

Before Kara, Aubrey and Helen considered their videos, they carefully reviewed their anecdotal notes, which included 
observations of the classroom atmosphere, daily schedule, student interactions, student comments, student participation, cooperating teacher involvement, and their own commentary about the day. In their records four students were mentioned in the day's notes less frequently: Student 1 (once), Student 2 (once), Student 3 (three times) and Student 4 (four times), in contrast to a learning disabled student (10 times) and a gifted student (8 times) in one day. Their manuscript revealed another surprise for them:

When demonstrating how to dissect a flower, Kara walked around and allowed every student to smell the flower, but became distracted by student behavior and bypassed Student 4. Student 4 clearly had been waiting, but said nothing when he was bypassed. At another point, he got up and left the class for five minutes with none of us acknowledging his absence [cognitive overload]. (Interview, fall 2012)

They decided that the four students mentioned less frequently in their records, whom they called their middle or invisible students, would become the subject of their study. In the upcoming understanding student learning section, Kara, Aubrey and Helen noted a fragmentation in learning of three out of their four "middle" students, an outcome from their perspective that would have been mediated by closer individual attention by the trio.

Several pairs/trios of students elected to study gender equality within their classrooms. For most, they found that they maintained a gender-neutral classroom in both the way they called on students during classroom discussions and within more informal interactions. However, for Audrey and Trevor, their analysis revealed that Trevor interacted with more than twice as many males as females during informal work time $\left(X^{2}=1.14, d f=1, p<0.285\right)$ while Audrey visited informally with almost twice as many females as males $\left(X^{2}=6.21, d f=1, p<0.0133\right)$. In their SOT paper they wrote: "We were shocked to look at the number of times we interacted with students of our own gender during less formal work time" [cognitive overload]. Although both teacher candidates interacted more often with their own sex, only Audrey's results were statistically significant. Unbeknownst to Audrey [cognitive overload], she illustrated a statistically significant gender preference towards her own sex, girls, during informal interactions with students while they worked on assignments or projects, a finding documented in the research literature (Lundeberg, 1997; Sadker, 1999).

\subsection{Classroom Discussion}

Like many teachers, the teacher candidates led classroom discussions with primarily teacher directed questions or probes and student responses related to the specific topics of their math and science lessons. Leading classroom discussion is considered to be one of the high-impact instructional routines in teaching because they occur frequently, are practices that are central to teaching, and facilitate learning of all students, including diverse learners (Ball \& Forzani). Many of the candidates noticed over and over again that the same students participated in the discussion [cognitive overload]. They also reflected on the types of questions they asked their students.

Increasing the number of students who participate in classroom discussion was the goal of the study completed by Emma, Carol and Ellie ( $4^{\text {th }}$ grade). They asked 68 questions total across their 5 lessons, with a majority of the questions being lower level questions using Bloom's taxonomy (1956). In math an example of a lower level question was, "What is a unit of measurement in customary measurement?" and a higher level questions was, "How can you change 5 feet into inches?" Of the 68 questions they asked, an average of 2.6 students would raise their hands to answer the question. If they did not allow for any wait time before calling on a student they had on average 1.6 students participate by raising their hand. When they followed the recommendations of (Rowe, 1974 a \& b) they had on average 3.6 students raise their hand to participate. Closer examination of their data revealed that 3 students answered nearly $40 \%$ of the 68 questions. They referred to this group of three as "lone raisers" because at least one of them raised their hand for most questions and wanted to give an answer within a second of a question being asked. "In our early lessons, we called on one student more often because we saw his hands go up, and without waiting, we called on him to share his answers" [cognitive overload] (SOT manuscript).

\subsection{Student Engagement}

Sustaining student engagement for novice teachers remains a formidable and anxiety producing challenge (Oral, 2012), thus it was not a surprise that many teacher candidates focused on this aspect of their practice. Marks' definition of engagement as "a psychological process, specifically, the attention, interest, investment, and effort students expend in the work of learning" (2000) will be used in this paper. Beatrice and Hannah taught five lessons in science and math in their second grade classroom for a total of 350 minutes of instruction. As they watched their videos they tallied how many students were actively attentive in the lessons. They were astonished to find that for the majority of the 350 minutes of instruction only $25 \%$ of their students were actively attentive in the content that they were teaching $(F=11.68$, $d f=2, p<.002$ ). They defined "active attention" as the number of students who appeared to be listening, paying attention, and completing the task or activities at two minute intervals during their lesson. In planning their lessons, they included a number of attention getters, but during the actual teaching, they rarely used those attention getters to refocus their 
students [cognitive overload].

In analyzing our video, we found that we did not use many attention getters or redirect students. Also, the majority of the lesson had 25\% or lower of students paying attention and participating in discussion during whole class activity. (SOT manuscript)

Instead, they found that they tended to talk over the students and push on with their lesson [cognitive overload], a common outcome for teacher candidates (Caudle, Jung, Fouts, \& Wallace, 2014).

In contrast, Angelique and Janel (multi-age grades 1-2) planned and used attention getters in their lessons (i.e. ringing a chime or asking students to "Gimme Five"). However, when they reviewed their videos they were stunned at the amount of time it took them to get the students attention [range was between 5 (chimes) and 28 seconds ("Gimme Five")]. Across their five lessons, they lost between 5 and 10 minutes of instructional time because of the multiple times they used an attention getter across a lesson and then waited for students to become completely focused. However, as their field experience continued, they found that if they practiced the attention getters first with their students and were specific about what their academic or behavioral expectations were for the students, the time needed to get the students attention decreased by half [germane load], a finding that was also documented by Gibson and Govendo (1991).

Kayla and Reese ( $5^{\text {th }}$ grade placement) found in their study that they often struggled with slowing down in lessons and taking time to wait for the entire class' attention before moving on to the next activity.

After watching our teaching videos, we noticed towards the end of the lessons we seemed to stop to regain students' attention less and less [cognitive overload]. I know we felt the pressure to finish our lesson on time [extraneous load] and trying to get through everything we planned [intrinsic load]. We also spent a lot of time preparing for each lesson [extraneous load] so if we took the time to think through and plan an engaging activity we wanted to make sure the students had the opportunity to participate in it [intrinsic load]. The lessons go by so fast and teachers do not want to spend time wasted on getting the class attention. (SOT manuscript)

It was not until they reviewed their video that they realized the scope of student disengagement during their teaching and subsequently did not develop "standard procedural routines that integrate management and instruction" (Kagan \& Tippins, 1992, p. 129), common challenges for teacher candidates (Caudle, et al.). The work of all three pairs are examples of how the teacher candidates uncovered and focused on an emerging habituated practice as a result of their practitioner research (Kesson, Traugh and Perez, 2006) and an opportunity to learn from that practice in short field placements at an early point in their preparation.

\subsection{Understanding Student Learning}

Padao and Heidi (second grade) analyzed examples of student work to understand learning in both math and science. Their results illustrated a mismatch between what they taught and what the students learned. In their first math lesson, they taught their second graders concepts of multiplication using an array model. Student work samples from the first day revealed that the students met the objectives of the lesson. The next day, they used the same array model, but to develop the concepts of division. They assumed that since the students caught on so well to the concept of multiplication the day before the students would be able to do the same for the division concept. That was not the case. The students struggled with the concept of division, a fact that was illustrated in the video record where during independent work time students had many procedural questions related to the math assignment and overall poor performance on the assessments. In science, they taught a series of three lessons on the bean plant life cycle that included a reading in the class science textbook. Although students were able to correctly sequence and draw the life cycle of a bean plant, their summative assessment revealed that the students did not comprehend the vocabulary (life cycle, plant, seed, grow, fruit, seed coat, roots, sprout, seedling, adult plant) because, as the teacher candidates noted in their manuscript, they did not focus on disciplinary literacy, which they had planned, in the science lessons (Quinn, et al.) [cognitive overload].

Monisha and Holly (first grade) found many places in their teaching where they could have done a better job of assessing the students. For example, during their math lessons, the students were in groups playing a dice game practicing subtraction with the numbers 9 and 10. They went over the instructions two times before the students started to play the game. While the students worked, they circulated through the room and answered questions and clarified directions. In watching their videos they discovered that a majority of the students had the same questions that they answered over and over again [cognitive overload], evidence to them that the students did not understand the directions in the first place. Watching their videos allowed them to find places in the lessons where simple formative assessments could have been included and would have provided them with the information they needed about what the students understood (Cauley \& McMillan, 2010).

As noted earlier in this manuscript, Kara, Aubrey and Helen found a difference in the attention they gave to the four 
students who they identified as the invisible middle in their fifth grade classroom. As part of their summative assessment they asked the students to complete questions about the science content (flower dissection, including the parts and functions of the flower and pollination). Student 1 remembered all the parts of the flower, what they looked like, and what their functions were. Student 2 wrote, "I learned that plants make seed from insides", but was not able to describe the function of each part. Student 3 wrote, "I learned that the pollen tubes are cool parts". Her exit card demonstrated that she remembered the structure of the pollen tubes, but not the function. This was in contrast to her knowledge of both the function and the structure of the ovary where during class she received individual attention from Kara. Student 4 was able to name the parts of the flower, not the function, and was able to describe some aspects of pollination. A caveat in his knowledge about pollination was that the specific details of pollination in his summative assessment were the bee carrying pollen from flower to flower, a concept that was acted out in his class. Student 3's knowledge of both the function and structure of the ovary after individual attention from Kara made the trio wonder if greater individual attention to students 1,3, and 4 would have increased their own complete knowledge of the unit, a claim supported by research in student engagement and achievement (Klem \& Connell, 2004).

This study opened our eyes to the "invisible child." This was an important revelation because our goal was to include all students. They were left out of our interactions because they were quiet, well behaved students who never complained or acted out. They were average to high-level students who simply got through the day by doing what was expected of them and were often bypassed because of the distraction of other students (SOT manuscript) [extraneous load].

\subsection{Grouping Students}

Six teacher candidate pair or trios focused their study of teaching on grouping students. The way in which teachers group students are important because grouping students impacts accessibility to and success in learning (Koomen, 2016; Stockall \& Gartin, 2002). Alissa and Eleanor (multi-age classroom of grades 1-3) had students work in a variety of groups while teaching their math and science lessons. Group work and activities were already a large part of the classroom context when they started their field experience. Their research focused on student engagement across the various groupings. They found that partner work was the most successful for the primary students, an outcome noted by Bancroft \& Rogers (2010). When they studied their groupings of three or more students they found that one student became less engaged while the other two continued doing the majority of the work, something they did not realize until they watched the videos of their teaching [cognitive overload]. Bancroft and Rodgers noted that as groups become larger there is the possibility of more sociological drama with a net effect that individual participation decreases.

Mohammed and Jennifer were placed in a sixth grade classroom where students were placed in "flexible grouping" by the teachers at the school for reading and mathematics. Students were assigned to a flexible group of either higher or lower "ability" in math, for example, based on their performance on summative unit tests and standardized testing in mathematics. Students could move up or down from a group as a result of subsequent performance on summative tests, thus the name "flexible" grouping. Mohammed and Jennifer's cooperating teacher taught both sections of math. The pair was interested to learn if knowing the ability of a student impacted whom they called on during classroom questions and response discussions. They taught the same math lessons to both section of students. However, students were not grouped by ability in science, thus they taught their science lessons to heterogeneous ability levels across two sections. Their research revealed that across both their math and science lessons they called on more higher ability students in math $\left(X^{2}=7.8, d f=1, p<0.0051\right)$ and also in science $\left(X^{2}=48.761, d f=1, p<0.0001\right)$. The results were unsettling to them because they thought they made an effort to call on both groups of students equally although they admitted to calling on the higher ability group because as teachers they were confident that those students would have the correct response [cognitive overload].

Often times, we called on the students in the upper class because they were first to raise their hand or because we were confident they knew the answer to our questions [cognitive overload]. This reflects a need for us to remember to use wait time more and give students the opportunity to think first and then talk to a partner or group about their thoughts before having students share their responses [germane load]. (SOT manuscript)

\subsection{Learning How to Learn from Practice}

The study of teaching allowed emerging teacher candidates to learn how to learn from practice. Helen talks about how the various research and data collection efforts built an understanding of an aspect of her teaching.

Our student interviews opened our eyes to the backgrounds and demeanors of the students we'd identified as the "middle" or "invisible" children in the classroom, while our interviews of teachers and support staff gave us a greater understanding of the actions and causes that contribute to the concept of the "middle" child. We also had the opportunity to watch videos of ourselves teaching. While watching these videos, we observed the "middle" students we had identified and took note of the time that each teacher spent with them. All of these 
research methods, along with our supporting articles, have opened our eyes to the problem of the "invisible child" and how we can address this in our future career as teachers [germane load]. (Helen: written reflection after completion of SOT)

Cambria articulates how practitioner research illustrated what she needs to work on as an emerging teacher.

The study of teaching was valuable to me because it allowed me to really look at my own teaching, and interaction with the students. Throughout our courses we look and study a lot about other teachers and theories of best practice, however by looking at my own teaching I am able to see the positives of my teaching and also the things I need to continue to work on in the classroom [germane load]. By studying my teaching, I was able to see that questioning was something I need to continue to work on in the future as I continue to teach. It has also taught me, that it is important to continue to study my own teaching, because unless I take the time to reflect and study what I do in the classroom, I won't know the things I need to improve on [germane load]. (Cambria: written reflection after completion of SOT)

The impact of her own study of teaching and hearing about the other research studies will impact Sierra long after she finishes her teacher education program

I think studying my teaching was valuable to me as was hearing what everyone else did. I knew that providing real-world application for students was beneficial, but I didn't realize just how beneficial until we wrote the paper. I feel like I was able to compile all of the little bits of information I had learned from here and there into one big compilation of everything I had learned [germane load]. This project will stay with me through student teaching and when I get my own classroom and I will keep it on a front burner while I am planning my lessons [germane load]. I also think that listening to other group's presentations will help me as I really feel like I learned a lot from them [germane load]. The one that is on my mind the most right now is Piper and Roberta's about the "average" student. I wonder if I do this myself. (Sierra: written reflection after completion of SOT)

Trevor acknowledges the power of learning how to learn from his own study with Audrey.

Understanding the problem that gender inequality can have on a classroom is so beneficial in the long run. How hard is it to change a habit that has become engrained in your mind? Knowing this issue at such an early age in my teaching career can help me shape my methods and outlook in the classroom, and ultimately benefit those involved [germane load]. From our continuous research and findings, we understood that just being AWARE of the fact that inequality may be prevalent in the classroom is a task in itself. How can you correct a problem when you don't even know that it is an issue [cognitive overload]? Realizing that this does happen in classrooms, and more times then not it is subconscious will only improve our teaching. It helps trigger our motivation when you can see the direct effects a teacher's tendencies have on the student, whether it is emotionally, cognitively, or other facets. Knowledge is power, but it does not mean a whole lot unless it is practiced effectively, which will be our next task as a teacher. Implementation can help us gauge what methods may work and others that do not (Trevor: written reflection after completion of SOT)

In an unsolicited email, Audrey commented on the impact of this project over a year after she completed the teacher education program.

In the beginning of the project, I was very overwhelmed. In the midst of five other classes and teaching in the classroom, my schedule was hectic and the project did not seem, in the beginning, to hold a lot of promise for unveiling any new information [extraneous load]. I had studied the topic of gender equality and was confident that I displayed this in my teaching. It was not until Trevor and I made the shocking discovery of our unknown bias during informal work times that I began to realize how powerful a study such as this could be. I graduated and am now teaching in my own classroom, and am proud to say that I consider this study often. It changed the way I thought about my own teaching, and opened my eyes up to the notion that gender bias during informal work times may not be the only unknown bias I show in my classroom. The long-lasting benefits of this study are not only that the students will graduate with new knowledge about habits they have in their teaching, but also with the knowledge of how to continue to do studies such as these [germane load]. (Audrey: Email exchange)

\section{Discussion}

The results of the practitioner inquiries provide evidence that the teacher candidates enhanced their learning from practice within practice as they studied their own teaching. Most teacher education programs develop a core knowledge of research based practice of the profession such as developing content specific lessons, monitoring and evaluating student learning and engagement, grouping students and supporting the diverse learners, to name just a few (Ball $\&$ Forzani). Even with this background, teacher candidates are challenged to assimilate that emerging knowledge of 
practice in the moments of their actual teaching. Cognitive load theory helps to explain why this challenge remains and also why there is a lag between theory and practice, which speaks to the second research question of this study. The working memory of teacher candidates must incorporate vast amounts of novel information all at the same time when they are teaching a lesson. The novel information is not tightly connected into schemata thus the working memory is overloaded. Expertise develops as learners mindfully combine simple ideas into complex and interconnected ideas (van Merriënboer \& Sweller, 2005) and achieve automaticity. Researchers have defined the characteristics of automaticity as: "a) it occurs without intention; b) is not subject to conscious monitoring; c) utilizes few, if any, attention resources; and d) happens rapidly" (Feldon, 2007, p. 126). Expert teachers have effectively structured teaching schemas that replace the diminished cognitive loads of novices (Feldon). Expert teachers effectively execute instructional and management routines with "little or no monitoring of execution" (Leinhardt \& Greeno, 1986, p. 94). In addition, the automaticity and effective teaching schemata enable experienced and expert teachers to use low levels of cognitive load thus they are more easily able to use mental resources to respond to the dynamics of teaching a lesson to a room full of students. Greater automaticity from the development of the schemata generates fast, and seemingly effortless performance (Feldon, 2007). Excessive cognitive load can prevent fully conscious and intentional reasoning by forcing some elements of teaching to be neglected [such as how engaged students are (Beatrice and Hanna; Kayla \& Reese), calling on the lone raiser (Emma, Carol \& Ellie; Mohammed \& Jennifer), or missing cues that students understood the content of the lesson (Holly \& Monisha; Padao \& Heidi)] or "pursued through nonconscious mechanisms" (Bargh \& Ferguson, 2000, p. 124). Thus, even though novice teacher candidates have learned about research-based and effective practices in their teacher education programs [like gender bias (Audrey \& Trevor) or inclusion of all students [Roberta \& Piper and Kara, Aubrey \& Helen)] overloaded working memory (cognitive overload) prevents their assimilation and delivery of these techniques within the moments of teaching. This also explains why cognitive overload was the element of CLT identified more frequently in the text excerpts of the current study.

Cognitive load theory can be used to explain the difficulty of assimilating theory into practice for emerging teacher candidates. Simultaneously focusing attention on content instructional strategies, engagement and attention of students, and the diverse learning needs of students, among other aspects of learning to teach in a classroom, overloads the working memory of the novice teacher (Moos \& Pitton; Feldon). Researchers have theorized that the challenge of attending to and integrating complex data and information as "split-attention effect" where the outcome is diminished performance because working memory is overloaded (Sweller, 1994; Chandler \& Sweller, 1991). In the current study, split attention effect explains the difficulty that the novice candidates had in maintaining student engagement, conducting a robust classroom discussion and the absence of inclusion of particular groups of students in their teaching. Novice teachers have difficulty sorting out irrelevant and distracting (extraneous load) information in their teaching, which increases the extraneous cognitive load and decreases their ability to think about the content and pedagogy of the lesson (intrinsic cognitive load) and assimilate the elements of information required of a teacher to build schema (germane cognitive load). For example, Beatrice and Hannah, explicitly included attention getters in their lesson plan, but failed to use them in the actual lesson. This failure to enact a planned strategy in the moments of teaching can be explained by CLT. Novice teachers, like Beatrice and Hannah, most likely were faced with cognitive overload during the actual teaching and thus did not have the cognitive resources available to use planned attention getters and redirection activities. Instead, they plowed through the content of their lesson unaware that only a small percentage of their students were engaged in learning and the lesson itself.

Moos and Pitton (2014) emphasize the importance for teacher candidates to develop "pockets of expertise" (p. 15) before they student teach. In the current study, the early program teacher candidates identified a practice for deeper study and thereby developed a pocket of expertise that presumably they will take with them into the final year of their teacher education program. Beatrice/Hanna, Kayla/Reese and Angelique/Janel have each built schemata or a pocket of expertise in their cognitive architecture around one element of teaching (student engagement) that hypothetically will enable them to use less working memory in this one element in their future teaching. Additionally, the evidence from this study illustrates that many of the teacher candidates (Helen, Cambria, Sierra, Trevor and Audrey) are building pockets of expertise (germane load) around learning how to learn from practice. Expertise is acquired through deliberate practice that advances automaticity, thus increasing the organization and schemata that are part of working memory. This key pocket of expertise sets the stage for them to develop greater automaticity and adaptively that may focus their attention to more germane cues (Feldon), all within the context of studying practice within practice and as early program teacher candidates.

Like many recent studies of practitioner research (Hostetler et al.; Mirick \& Davis, 2015; Valli, 2000) the teacher candidates focused primarily on general instructional strategies and methods well reported in the research literature, an outcome that aligns with the theory of cognitive load. Those general instructional strategies are the ones that stuck out to them when they reviewed their videos. Reviewing videos of teaching also stretches cognitive load for novice teacher 
candidates. Undoubtedly there were other areas of practice that they did not "see" as they conducted their video analysis, simply because their working memory was overloaded. They chose a facet of their teaching to study that was more explicit to them which places the teacher candidate studies into the category of educational connoisseurs (Eisner, 1976) in their application of practitioner inquiry. Depending on the topic they researched, the individual pairs/trios have a better understanding and appreciation of the degree of inclusion, leading student discussions, promoting student engagement, assessing students and grouping students for class activities. Their cognitive schemata now include understanding why those practices are important, how they played out in their own teaching across different curricular areas and how their findings align with the research literature. Like the practitioner inquiry of Hostetler, et al. (2013), their work struck a pragmatic and confirmatory balance between critique of themselves and their success and growth as teachers.

\section{Limitations}

One of the limitations of this study is that there was no significant follow-up of the candidates once they went into student teaching. At the conclusion of the project (the end of the methods semester) it was clear that they learned about their own practice from practice. However, because they were not followed into student teaching the actual change in practice is uncertain. Future research might address the change in practice that occurs after completing practitioner research as novice teacher candidates move into student teaching. Second, the candidates are novice researchers as well as novice teachers. It was beyond the scope of the work of this project, especially the time constraints that are part of a one-semester course 15-16 week course, to do a thorough literature review of the topics under study. The teacher candidates also learned basic qualitative research methods. Close inspection of their interview transcripts reveal a number of novice researchers' blunders including leading questions of the interviewer and failure to probe an interviewee's response for greater clarity. In addition, throughout the process the teacher candidates and the author participated in mentored conversations around the design of the study, the data collection, the analysis and the outcomes. Future studies might broaden those conversations to enable teacher candidates to provide feedback and mentoring to each other.

\section{Conclusion}

Despite the limitations listed above, this study sheds light on how we can foster learning from practice in practice with early program novice teachers with implications for teacher education. First, practitioner inquiry can be conducted in short field experiences with early program teacher candidates. The pairs and trios of teacher candidates were initiated into the complex, situated, and expansive view of the work of teaching (Hatch \& Grossman, 2009) by their teacher researcher stance. They, in fact, witnessed first-hand that learning teaching includes both what we learn in our formal education in colleges and universities, but also what we learn through studying our own practice. Their studies "fostered learning about and from practice in practice" and thus addresses the gap identified by Darling-Hammond for teacher education. The roots of this practitioner research originate in the issues, dilemmas, questions, or wonderings that interested them. Their close examination of their teaching enabled them to see an event in a way that they had not seen it before (Rhine and Bryant, 2007), all at a time when they were early program teacher candidates within short field experiences, an underreported area of teacher education. This work with teacher candidates affirms the value and the feasibility of fieldwork coupled with practitioner research noted by other researchers (Hostetler, et al.). The power of this work is in its ability to uncover unintentional practices of early educators so they can improve their practice early on in their teacher preparation programs and thus become well-started novices (Sykes et al.), a significant outcome for us as teacher educators. In addition, practitioner research coupled with short field experiences might offer flexible ways of including this promising practice in teacher programs that struggle to fit everything in.

Second, using practitioner research with rising teacher candidates allows them to learn how to learn from practice at an early point in their careers and will offer benefits to them as they continue through their teacher education programs. They understand the value of practitioner inquiry for them as future teachers and understand some of the nuances of how to go about doing practitioner inquiry on their own teaching. They have a more holistic understanding of how you pull various aspects of both teaching and research to understand deeply a facet of their practice. They will go on to student teaching and into their first years in the field knowing how to do studies such as the ones reported here.

Third, a value of practitioner inquiry with novice teacher candidates using the theoretical lens of cognitive load provides information to us as teacher educators where beginning teachers may face cognitive overload and thus paves the way for us to offer ways to support them. For one, most teacher education programs require teacher candidates to write lesson plans but, as the results of this study indicate, not all planned and at times critical aspects of the lessons, were delivered in the moments of teaching. Perhaps we as teacher educators can develop in the moment-of-teaching check lists with a short list of items or questions to refer to during teaching (for example: Got and use attention getters? or Who is responding to your questions and who is not?).

Fourth, a review of teaching episodes through videotaped analysis illustrate facets of practice that are overlooked in the 
moments of teaching due to cognitive overload. This study affirms the importance of videotaped analysis for early program novices, even without the in-depth practitioner inquiry, as a way to isolate and improve pockets of expertise (Moos \& Pitton). Teacher education programs might embrace videotaped analysis with entry-level novice teacher candidates. Videotape analysis of even brief teaching episodes might illustrate to teacher candidates the moments of teaching, like Beatrice and Hanna where they are experiencing cognitive overload. Second, videotaped analysis early in teacher education programs may reduce cognitive load in certain practices as entry-level novices build their schemata and develop their pockets of expertise.

\section{References}

Allen, R. M., \& Casbergue, R. M. (1997). Evolution of novice through expert teachers' recall: Implications for effective reflection on practice. Teaching and Teacher Education, 13(7), 741-755. http://dx.doi.org/10.1016/S0742-051X(97)00018-8

Ball, D. L., \& Forzani, F. M. (2009). The work of teaching and the challenge for teacher education. Journal of teacher education, 60(5), 497-511. http://dx.doi.org/10.1177/0022487109348479

Bancroft, A., \& Rogers, S. (2010). Georg Simmel-The Significance of Numbers for Social Life. Retrieved from Cardiff University: http://www.cf.ac.uk/socsi/undergraduate/introsoc/simmel9.html

Bargh, J. A., \& Ferguson, M. J. (2000). Beyond behaviorism: on the automaticity of higher mental processes. Psychological bulletin, 126(6), 925. http://dx.doi.org/10.1037/0033-2909.126.6.925

Berliner, D. C. (1986). In pursuit of the expert pedagogue. Educational researcher, 5-13. http://dx.doi.org/10.3102/0013189X015007007

Blessing, S. B., \& Anderson, J. R. (1996). How people learn to skip steps. Journal of experimental psychology: learning, memory, and cognition, 22(3), 576. http://dx.doi.org/10.1037/0278-7393.22.3.576

Bloom, B. S. (1956). Taxonomy of Educational Objectives: The Classification of Education Goals. Cognitive Domain. Handbook 1. Longman.

Calandra, B., Gurvitch, R., \& Lund, L. (2008). An exploratory study of digital video as a tool for teacher preparation. Journal of Technology and Teacher Education, 16(2), 137-153.

Caudle, L. A., Jung, M. J., Fouts, H. N., \& Wallace, H. S. (2014). Early Childhood Preservice Teachers' Use of Verbal and Non-Verbal Guidance Strategies Across Classroom Contexts. The Teacher Educator, 49(1), 61-74. http://dx.doi.org/10.1080/08878730.2013.848004

Cauley, K. M., \& McMillan, J. H. (2010). Formative assessment techniques to support student motivation and achievement. The Clearing House: A Journal of Educational Strategies, Issues and Ideas, 83(1), 1-6. http://dx.doi.org/10.1080/00098650903267784

Chandler, P., \& Sweller, J. (1991). Cognitive load theory and the format of instruction. Cognition and instruction, 8(4), 293-332. http://dx.doi.org/10.1207/s1532690xci0804_2

Chi, M. T. H., Glaser, R., \& Rees, E. (1982). Expertise in problem solving. In R. Sternberg (Ed.), Advances in the Psychology of Human Intelligence, 1, 7-76. Hillsdale, NJ: Erlbaum.

Cochran-Smith, M. (1991). Learning to teach against the grain. Harvard Educational Review, 51(3), 279-310. http://dx.doi.org/10.17763/haer.61.3.q671413614502746

Cochran-Smith, M. (1995). Color blindness and basket making are not the answers: Confronting the dilemmas of race, culture, and language diversity in teacher education. American Educational Research Journal, 32(3), 493-522. http://dx.doi.org/10.3102/00028312032003493

Cochran-Smith, M. (1999). Learning to teach for social justice. In G. Griffin (Ed.), The education of teachers: Ninety-eighth yearbook of the national society for the study of education (pp. 114-144). Chicago, IL: University of Chicago Press.

Cochran-Smith, M., \& Lytle, S. (2009). Inquiry as stance: Practitioner research for the next generation. New York: Teachers College Press.

Cochran-Smith, M., \& Lytle, S. L. (2004). Practitioner inquiry, knowledge, and university culture. In J. Loughran, M. L. Hamilton, V. LaBoskey \& T. Russell (Eds.), International handbook of research of self-study of teaching and teacher education practices (pp. 601- 649). Amsterdam: Kluwer.

Cochran-Smith, M., Barnatt, J., Friedman, A., \& Pine, G. (2009). Inquiry on inquiry: Practitioner research and students' learning. Retrieved August 27, 2013. http://dx.doi.org/10.1080/01626620.2009.10463515 
Daiker, D. A., \& Morenberg, M. (1990). The writing teacher as researcher. Portsmouth, NH: Boynton/Cook.

Darling-Hammond, L. (2010). Teacher education and the American future. Journal of Teacher Education, 61(1-2), 35-47. http://dx.doi.org/10.1177/0022487109348024

Edelsky, C. (1991). Whole language: What's the difference?. Heinemann Educational Books.

Eisner, E. W. (1976). Educational connoisseurship and criticism: Their form and functions in educational evaluation. Journal of Aesthetic Education, 135-150. http://dx.doi.org/10.2307/3332067

Feiman-Nemser, S. (2001). From preparation to practice: Designing a continuum to strengthen and sustain teaching. The Teachers College Record, 103(6), 1013-1055. http://dx.doi.org/10.1111/0161-4681.00141

Feldon, D. F. (2007). Cognitive load and classroom teaching: The double-edged sword of automaticity. Educational Psychologist, 42(3), 123-137. http://dx.doi.org/10.1080/00461520701416173

Gibson, B. P., \& Govendo, B. L. (1999). Encouraging constructive behavior in middle school classrooms a multiple-intelligences approach. Intervention in school and clinic, 35(1), 16-21. http://dx.doi.org/10.1177/105345129903500103

Gobet, F., \& Simon, H. A. (1998). Expert chess memory: Revisiting the chunking hypothesis. Memory, 6(3), 225-255. http://dx.doi.org/10.1080/741942359

Hatch, T., \& Grossman, P. (2009). Learning to look beyond the boundaries of representation: Using technology to examine teaching (Overview for digital exhibition: Learning from the practice of teaching). Journal of Teacher Education, 60(1), 70-85. http://dx.doi.org/10.1177/0022487108328533

Hiebert, J., \& Morris, A. K. (2012). Teaching, rather than teachers, as a path toward improving classroom instruction. Journal of Teacher Education, 63(2), 92-102. http://dx.doi.org/10.1177/0022487111428328

Hostetler, A. L., Hawley, T. S., Crowe, A. R., Smith, E., Janosko, A., Koppes, L., \& Loudin, A. (2013). Self-study of Practice as a Framework to Promote Growth in the Student Teaching Experience. Studying Teacher Education, 9(2), 187-200. http://dx.doi.org/10.1080/17425964.2013.808064

Kagan, D. M., \& Tippins, D. J. (1992). How US preservice teachers 'read 'classroom performances. British Journal of Teacher Education, 18(2), 149-158. http://dx.doi.org/10.1080/0260747920180204

Kesson, K., Traugh, C., \& Perez, F. (2006). Descriptive inquiry as contemplative practice. Teachers College Record, 108(9), 1862-1880. http://dx.doi.org/10.1111/j.1467-9620.2006.00765.x

Kirschner, P. A., Ayres, P., \& Chandler, P. (2011). Contemporary cognitive load theory research: The good, the bad and the ugly. Computers in Human Behavior, 27(1), 99-105. http://dx.doi.org/10.1016/j.chb.2010.06.025

Klem, A. M., \& Connell, J. P. (2004). Relationships matter: Linking teacher support to student engagement and achievement. Journal of school health, 74(7), 262-273. http://dx.doi.org/10.1111/j.1746-1561.2004.tb08283.x

Koomen, M. H. (2016). Inclusive science education: Learning from Wizard. Cultural Studies in Science Education, 1(11). http://dx.doi.org/10.1007/s11422-015-9668-6

Lampert, M. (1990). When the problem is not the question and the solution is not the answer: Mathematical knowing and teaching. American educational research journal, 27(1), 29-63. http://dx.doi.org/10.3102/00028312027001029

Leinhardt, G., \& Greeno, J. G. (1986). The cognitive skill of teaching. Journal of educational psychology, 78(2), 75. http://dx.doi.org/10.1037/0022-0663.78.2.75

Lesh, R., \& Kelly, A. (2000). Multitiered teaching experiments. In A. E. Kelly \& R. A. Lesh (Eds.), Handbook of research design in mathematics and science education (pp. 197-231). Mahwah, NJ: Lawrence Erlbaum Associates.

Levin, B. B. \& Rock, T. C. (2003). The effects of collaborative action research on pre-service and experienced teacher partners in professional development schools. Journal of Teacher Education, 54(2), 135-150. http://dx.doi.org/10.1177/0022487102250287

Lundeberg, M. A. (1997). You guys are overreacting: Teaching prospective teachers about subtle gender bias. Journal of Teacher Education, 48(1), 55. http://dx.doi.org/10.1177/0022487197048001008

Marks, H. M. (2000). Student engagement in instructional activity: Patterns in the elementary, middle, and high school years. American educational research journal, 37(1), 153-184. http://dx.doi.org/10.3102/00028312037001153

Masunaga, H., \& Horn, J. (2000). Characterizing mature human intelligence: Expertise development. Learning and individual differences, 12(1), 5-33. http://dx.doi.org/10.1016/S1041-6080(00)00038-8

Miller, O. A. (1956). The magical number seven, plus or minus two: Some limits on our capacity for processing 
information. Psychol. Rev., 63, 81-97. http://dx.doi.org/10.1037/h0043158

Mirick, R. G., \& Davis, A. (2015). A clinician in the classroom: using a reflective practice paradigm to learn to teach. Reflective Practice, 16(2), 182-194. http://dx.doi.org/10.1080/14623943.2014.992404

Moos, D. C., \& Pitton, D. (2014). Student teacher challenges: Using Cognitive Load Theory as an explanatory lens. Teaching Education, 25(2). http://dx.doi.org/10.1080/10476210.2012.754869

Oral, B. (2012). Student Teachers' Classroom Management Anxiety: A Study on Behavior Management and Teaching Management. Journal of Applied Social Psychology, 42(12), 2901-2916. http://dx.doi.org/10.1111/j.1559-1816.2012.00966.x

Price, J. (2001). Action research, pedagogy, and change: The transformative potential of action research in preservice teacher education. Journal of Curriculum Studies, 33(1), 43-74. http://dx.doi.org/10.1080/00220270118039

Price, J. N., \& Valli, L. (2005). Preservice teachers becoming agents of change: Pedagogical implications for action research. Journal of Teacher Education, 56(1), 57-72. http://dx.doi.org/10.1177/0022487104272097

Quinn, H., Lee, O., \& Valdés, G. (2012). Language demands and opportunities in relation to Next Generation Science Standards for English language learners: What teachers need to know. Commissioned Papers on Language and Literacy Issues in the Common Core State Standards and Next Generation Science Standards, 94, 32.

Rhine, S., \& Bryant, J. (2007). Enhancing pre-service teachers' reflective practice with digital video-based dialogue. Reflective Practice, 8(3), 345-358. http://dx.doi.org/10.1080/14623940701424884

Richardson, V. (1994). Conducting research on practice. Educational Researcher, 23(5), 5-10. http://dx.doi.org/10.3102/0013189X023005005

Rock, T. C., \& Levin, B. B. (2002). Action Research Projects: Enhancing Preservice Teacher Development. Teacher Education Quarterly.

Rowe, M. B. (1974a). Relation of wait-time and rewards to the development of language, logic, and fate control: Part IIRewards. Journal of Research in Science Teaching, 11(4), 291-308.

Rowe, M. B. (1974b). Wait-time and rewards as instructional variables, their influence on language, logic, and fate control: Part I- Wait-time. Journal of Research in Science Teaching, 11(2), 81-94.

Rubin, H. J., \& Rubin, I. S. (2004). Qualitative interviewing: The art of hearing data. Thousand Oaks, CA: Sage.

Sadker, D. (1999). Gender equity: Still knocking at the classroom door. Educational Leadership, 56, 22-27.

Salomon, G. (1984). Television is "easy" and print is "tough": The differential investment of mental effort in learning as a function of perceptions and attributions. Journal of Educational Psychology, 76, 647-658. http://dx.doi.org/10.1037/0022-0663.76.4.647

Seidel, J. V. (1998) Qualitative Data Analysis, www.qualisresearch.com (originally published as Qualitative Data Analysis, in The Ethnograph v5.0: A Users Guide, Appendix E, 1998, Colorado Springs, Colorado: Qualis Research).

Sherin, M. G. (2000). Facilitating meaningful discussions about mathematics. Mathematics Teaching in the Middle School, 6(2), 186-190.

Sherin, M. G. (2004). New perspectives on the role of video in teacher education. In J. Brophy (Ed.), Using video in teacher education (pp. 1-27). NY: Elsevier Science.

Sternberg, R. J., \& Horvath, J. A. (1995). A prototype view of expert teaching. Educational researcher, 24(6), 9-17. http://dx.doi.org/10.3102/0013189X024006009

Stockall, N., \& Gartin, B. (2002). The nature of inclusion in a blue ribbon school: a revelatory case. Exceptionality, 10(3), 171-188. http://dx.doi.org/10.1207/S15327035EX1003_2

Strauss, A. L., \& Corbin, J. (1998). Basics of qualitative research: Techniques and procedures for developing grounded theory. Thousand Oaks, CA: Sage.

Sweller, J. (1988). Cognitive load during problem solving: Effects on learning. Cognitive Science, 12, $257-285$. http://dx.doi.org/10.1207/s15516709cog1202_4

Sweller, J. (1994). Cognitive load theory, learning difficulty, and instructional design. Learning and instruction, 4(4), 295-312. http://dx.doi.org/10.1016/0959-4752(94)90003-5

Sweller, J. (1999). Instructional Design in Technical Areas. Australian Education Review, No. 43. PCS Data Processing, Inc., 360 W. 31st, New York, NY 10001. 
Sweller, J., Van Merrienboer, J. J., \& Paas, F. G. (1998). Cognitive architecture and instructional design. Educational psychology review, 10(3), 251-296. http://dx.doi.org/10.1023/A:1022193728205

Sykes, G., Bird, T., \& Kennedy, M. (2010). Teacher education: Its problems and some prospects. Journal of Teacher Education, 61(5), 464-476. http://dx.doi.org/10.1177/0022487110375804

Valli, L. (2000). Connecting teacher development and school improvement: Ironic consequences of a preservice action research course. Teaching and teacher Education, 16(7), 715-730. http://dx.doi.org/10.1016/S0742-051X(00)00021-4

Van Merriënboer, J. J., \& Sweller, J. (2005). Cognitive load theory and complex learning: Recent developments and future directions. Educational psychology review, 17(2), 147-177. http://dx.doi.org/10.1007/s10648-005-3951-0

\section{$(\infty)$ EY}

This work is licensed under a Creative Commons Attribution 3.0 License. 